\title{
From the History of The Study of The Saks' Monuments in The Lower Syr Darya And Amu Darya Basins
}

\author{
Utkir Abdullaev, Urgench State University Republic of Uzbekistan \\ Ahmadjon Yusupov, Urgench State University Republic of Uzbekistan
}

\begin{abstract}
The following article is dedicated to the history of the study of the Saks' monuments in the lower Syr Darya and Amu Darya basins. The main attentionis focused on the scientific works of historians on the theme and the ideas in them have been reacted.
\end{abstract}

Keywords: the Amu Darya, the Syr Darya, Aral Sea regions, Red Horde, Babishmulla, Saks, the Inkadarya River, the Jonidarya River, Tagisken, Chirikrabot, Jetiosor.

$\begin{array}{lll}\text { Received: 09.12.2020 } & \text { Accepted: 18.01.2021 } & \text { Published: 02.02.2021 }\end{array}$

\section{INTRODUCTION AND RELEVANCE}

The fact that In the works of Greco-Roman authors, the Syr Darya - Yaksart is described as the border of nomadic areas, the Khorezm oasis is inhabited by the Apasiak and Sakawarka tribes and the Sogdian leader Spitamen withdrew from Alexander's army to the steppes, was one of the reasons that led to the beginning of archeological investigations in the Syr Darya basin in 1946[1]. Because the history and culture of the Saks was not thoroughly explored.

The lower Syr Darya, which joins the Aral Sea from the east, is a large plain. Its width is $400 \mathrm{~km}$ and in the meridian line, this plane intersects $200-250 \mathrm{~km}$. It is bordered on the north and northeast by the modern valley of the Syrdarya and on the south by the Kyzyl-kum. These areas are geographically called the "Eastern Aral Sea regions"[2].

The origin of this vast steppe plain is associated with the efforts of the ancient rivers of the Syr Darya, changing the direction of the water at different times and flowing into the Aral Sea. In the plains there are rivers called Inkardarya, Jonidarya, Kuvandarya and Eskidarya, which consist of a system of ancient tributaries of the Syr Darya. They started in the south of what is now the Red Horde.

The geographical environment of the Eastern Aral Sea region, warm and humid air, abundance of fresh water have long created favorable conditions for human life. Thus, these factors influenced the economy, lifestyle and material culture of the ancient population of the Lower Syr Darya and played an important role in the development of historical processes.

\section{RESEARCH METHODS}

The ruins of the city and other archeological monuments located in the eastern part of the Aral Sea and in the middle part of the Syrdarya were first described historically and geographically in the late $19^{\text {th }}$ - early $20^{\text {th }}$ centuries[3]. Archaeological excavations of the Khorezm expedition, which began in 1946, continued until 1992 with breaks. As a result, many monuments of the Neolithic and Bronze Ages, the Early Iron Age and the Antiquity were discovered.

In $300 \mathrm{~km}$ southwest of the Red Horde (Janidarya oasis), the ruins of the city Chirikrabot of the Saks were found and examined, which is peculiar to in the $5^{\text {th }}-2^{\text {nd }}$ centuries BC. It has an ovoid history and covers an area of more than 50 hectares. Chirikrabot is surrounded by a trench and two rows of defensive walls. The walls are reinforced with rectangular defensive towers and have internal corridors for firing[4].

According to S.P. Tolstov, Chirikrabot was the center of the association of the Apasiak tribes. Simultaneously with this monument, Babishmulla began to be examined. It is located $40 \mathrm{~km}$ northeast of Chirikrabot and consists of a rectangular inner fortress (area 1 hectare) and the ruins of a town occupying 2 hectares. S.P. Tolstov wrote that this fortified town should be the center of one of the Apasiak tribes and the residence of the chief of the tribe. 40 burial structures belonging to the Chirikrabot culture, the ruins of mausoleums made of raw bricks were inspected. Most of them have a circular shape, two of them are rectangular in shape. Eighteen of these tombs have been excavated[5]. 


\section{RESEARCH RESULTS}

The owners of the Chirikrabot culture lived a sedentary and semi-sedentary lifestyle. They knew the artificial irrigation system. The settlements are made of mud bricks and are located separately around the castles[6].

A large group of Sak monuments has been identified in the Jetiosor oasis adjacent to the Eskidarya River in the Syrdarya. It is located north of the Inkardarya and Janidarya rivers, southwest of the presentday city of Jusali. Archaeological research was conducted in 1948-1949, 1951 (S.P. Tolstov, Y.A. Rapoport, M.A. Orlova, T.A. Zhdanko) and in 1973-1991, was performed under the direction of L.M. Levina.

The geographical conditions, location and topography of the monuments of Jetiosor were originally determined by S.P. Tolstov. According to the scientist, the Jetiosor district is connected to the Jusali steppe in the north, and in the west this steppe changes and goes to the bottom of the Kuvondarya river and turns into sand dunes. All the identified monuments are associated with the main river of Eskidarya or its tributaries, i.e. all the monuments are located near the river and the banks of the tributaries.

The monuments are divided into three main types according to their features and topographic characters, including small castles surrounded by defensive walls, fortified walls with towers and dwellings inside, large fortifications with highly developed fortifications, castles (Oltinosor 2, 3). These forts of the Saks were discovered to have been built in the middle of the first millennium BC.

Simultaneously with the study of the Chirikrabot and Jetiosor monuments, extensive exploratory archeological work was carried out in the lower Syr Darya region. As a result, in 1959, more than 70 burial mounds belonging to cattle-breeding tribes were found along the banks of the Inkardarya River, $200 \mathrm{~km}$ southwest of the city of the Red Horde. They are divided into northern and southern Tagisken groups. Instead of 11 forts in northern Tagisken, remains of mausoleums made of raw bricks of $9^{\text {th }}-8^{\text {th }}$ or $10^{\text {th }}-8^{\text {th }}$ centuries were excavated. Archaeological excavations have revealed that the 1960-1961 made under the direction of M.A. Itina. The results of the research are covered in a special article[7].

Burial structures, with advanced building techniques and architectural history, consist of rectangular and ring tombs. As an example, the mausoleum №5a consists of a rectangular structure with sides $18 \mathrm{~m}$ and a round section (diameter $14 \mathrm{~m}$ ) separated by a circular corridor inside. Even larger, inside the $25 \mathrm{~m}$ diameter ring mausoleum, there is a rectangular burial structure. A corridor separated the outer and inner parts of all tombs (including №4a, 5v). Remains of columns made of raw bricks and pits for the installation of wooden columns were found carved in the central parts of their burial grounds. In ancient times, the height of the tombs was about 6-8 meters, and in such large structures he tribal leaders and tribal elders of the first nomads were buried.

Among the monuments found on the banks of the Inkardarya, the Southern Tagisken and Uygarak tombs, which belong to the first Saks culture of the $7^{\text {th }}-5^{\text {th }}$ BC centuries, are distinguished. Between 1961 and 1965, 70 burial mounds were excavated in the ancient Uygarak cemetery[8]. The results of the study were covered in the work of O.A. Vishnevskaya[9].

The height of the Uygarak tomb mounds is 1-2 meters, some of the mounds are much larger and have a diameter of 20-22-27 meters. O.A. Vishnevskaya, who identified the burial customs of the Saks in Uygarak Cemetery, divided the studied ancient tombs into: rectangular pits, the corpses buried in clothes and shoes, the tops of the tombs covered with reeds; the walls are made of wooden huts, hut tombs, corpses are placed on the ground. Also there were found wooden columns mounted in two rows of pits, and tombs with wooden walls. They were covered with sticks and reeds, in which the dead were cremated.

Various burial equipment (household items, pottery, weapons, jewelry) were found in the burial mounds of Uygarak[10]. This habit was associated with the notion of the "other world". In the tombs of men and women there are pottery vessels, which are placed near the head or feet of the corpses. Some tombs contain pieces of the meat of sacrificial animals. This is evidenced by the spine, ribs and skulls of sheep found in graves.

Among the burial equipment of men's graves, there are horse harnesses, bullet points, bronze and iron daggers, and thin, sharp stones designed to sharpen them. In the graves of the women there are beads, jewels, bracelets and bronze mirrors, in addition to the items related to household activities in life - quilts and ruffled heads.

As a result of the archaeological excavations in the Lower Syr Darya region, Saks' monuments unknown to history, were duscovered. Archaeological excavations of the Late Bronze Age North Tagisken burial site have also come as a surprise to archaeologists, as there are no monuments of raw brick and intricate architecture in the Eurasian steppe, including the Southern Urals, Central and Northern Kazakhstan, and Western Siberia.

Due to the study of the Chirikrabot and Jetiosor cultures of the Khorezm expedition, it became clear that by the middle of the first millennium BC, the Saks began to use raw bricks and wattle and daub as 
building materials. This is evidenced by the ruins of large cities, towers and castles with shooting ranges, which belong to the Jetiosor culture and are surrounded by defensive walls[11]. Although cattle-breeding played an important role in the life of the Lower Syr Darya communities during this period, the majority of the population were not nomads. Archaeological excavations have revealed that the population groups of the lower Syr Darya belong to semi-settled cattle-breeders[12]. This cultural innovation took place in the second stage of the history of the Saks, manifested in the $5^{\text {th }}-3^{\text {rd }}$ centuries BC.

Material objects found in the Uyghur burial mounds are of great importance in determining the history and culture of the Sak tribes, which developed shortly before the above-mentioned processes.

Taking into account the information received, S.P. Tolstov highlighted the main features of the culture of the Eastern Aral Sea Saks, the Sak-Massagets and the Scythians and Sarmatians, as well as economic and cultural relations with the ancient cattle breeders of Kazakhstan and Siberia[13].

From the beginning of the scientific activity of the Khorezm expedition (1937) until the 70s of the $20^{\text {th }}$ century, the possibility of the spread of Saks in the Khorezm oasis, i.e. in the South Aral Sea region, was not discussed. The Sak-Massaget tribes were traditionally considered to be seasonal settlers in the steppes surrounding the oasis.

In 1970, Kanga 2 was discovered on the left bank of the Amu Darya River on the banks of the Dovdon basin in northern Sariqamish regions (northern Turkmenistan). Based on the fragments of pottery found there, it was marked by the first half of the $1^{\text {st }}$ millennium BC[14].

Subsequent research has shown that the age of the monument is marked as the end of the $7^{\text {th }}$ century and the middle of the 6th century. According to researcher D. Durdiev, this settlement, which probably served as a "shelter for nomadic pastoralists" in the middle of the $6^{\text {th }}$ century BC, was destroyed by a progressive army of Ahamanid Persians[15]. Chronologically, a mistake was made here, as the march of the Persian king Cyrus II against the Massagets took place much later.

Archaeological materials found in Kanga 2, mainly hand-made pottery, were compared with pottery of the late Bronze Age Amirabad culture studied on the right bank of the Amu Darya, and it was concluded that the communities inhabited the settlement were engaged in animal husbandry.

In 1971, on the banks of the ancient Dovdon River, the second settlement of cattle breeders of $7^{\text {th }}$ $6^{\text {th }}$ centuries - Quyisoy 2 was found. It is located on an area of about 11-12 hectares and it is not surrounded by defensive walls, no traces of wattle and daub or raw brick construction have been found in the monument, the population lived in huts, wooden-columned hut-walled huts and tents[16].

According to all indications, no traces of dwellings, handicrafts, ancient artificial irrigation facilities around the settlement were found, indicating that the communities of the Kuyisay culture were cattle breeders. As a result of the study of the Tumekkichijik burial mounds in the Dovdon oasis, burial customs belonging to cattle breeders known from the Uygarak excavations were revealed. In particular, the following similarities are noteworthy: the burial of the dead in the center of the tombs, the cremation of corpses in the tombs, the presence of necklaces in the graves of women, stone bedspreads and pottery.

Taking into account the general appearance of the Kuyisay material culture (pottery, iron knives, bronzeware, horseshoes, pottery, turquoise, lapis lazuli and limestone necklaces) as well as the characteristics of the settlements, B.I. Weinberg initially concluded: "In general, the Kuyisay culture must undoubtedly belong to the Saks (in the broadest sense of the word)". But in the years that followed, that view began to change, and unexpectedly, the researcher connected people of Kuyisay with Iranianspeaking herdsmen settled in northern Iran in the $7^{\text {th }}$ century BC and migrated to the Khorezm oasis in the middle of that century[17].

B.I. Weinberg writes that the Aral Sea Saxons moved to the eastern regions of Midia in the $7^{\text {th }}$ century BC, as a result of military campaigns, these Iranian-speaking Khorasan herders (voluntarily or compulsorily) were relocated to Sariqamish. Thus the researcher developed his views considerably, although they were not proved by written and archaeological data.

Such an approach became controversial, as in the early 1980s, the question of the belonging of the Kuyisay people to the Saks culture was once again raised[18]. According to M.A. Itina, the peculiarity of the Kuyisay culture of the $7^{\text {th }}-4^{\text {th }}$ centuries BC is that in its first stage two cultural strata are clearly visible, including: pottery from the south-west of Central Asia (Dohistan) and from the south (Margiana) and northern, local, Saks, i.e. it was suggested that the spread of the Sak tribes in the Khorezm steppes by the Early Iron Age is probable.

Paleontropological materials also contradicted the idea that the Kuyisays originated in northeastern Iran or Eastern Midia. T.A. Trofimova, as a result of studying the skulls of cattle breeders from the tombs of Tumekichijik and Tarimkoya 1, noted that the anthropological features of the Kuyisay belonged to the Eurasian steppe tribes[19]. But in this regard, according to B.I. Weinberg, anthropological data cannot be used as a basis for linking the process of the emergence of lowlands with the northern regions of Central Asia and the steppe tribes of Kazakhstan[20]. To this conclusion, M.A. Itina protested, 
tracing the local steppe roots of the Kuyisay culture[21]. At the height of this controversy, in 1981, an employee of the Khorezm Archaeological Expedition, under the leadership of L.T. Yablonsky, excavations began in the tombs of the first Saks found in Sakarcha or Kuyisay hills around the Sariqamish regions Dovdon valley[22]. Their results could clarify the scientific debate.

Various structures of ancient tombs have been identified in the Sakarchaga burial mounds, including: tombstones made of limestone, large rectangular tombs with corpses placed in reed tissue; graves surrounded by two rows of limestone on the ground, the body buried in their central part and covered with a tombstone consisting of earth; a tomb-shaped tomb in the form of a columnar-sided hut, the walls of which are broken on the ground, and the dead are placed in its center; surrounded by limestone, round-shaped hut-pillar-sinch tombs, in which corpses were cremated[23].

A study of the Sakarchaga and Uygarak burial mounds revealed commonalities in the burial ceremonies and equipment found in the tombs of the Aral Sea Saks. Laying the dead on traditional reed beds or mats, installing wooden pillars around the sides of the graves without filling the graves with soil, and covering the graves with mats and canopies, as well as large rectangular, columnar-shaped graves resembling basement-column dwellings. These include customs such as building "homes for the dead" and cremation.

The remarkable features of the described funerals are that they are reflected in written sources, in Herodotus' stories about Scythian burial customs: "A large rectangle is dug deep into the ground... The body is laid in a tomb, covered with stakes and reed mats".

Burial utensils from the tombs of Sakarcha include pottery, household utensils and weapons, pottery, jewelry, horse equipment, and items used in religious ceremonies, such as the South Tagisken and Uygarak finds. These include beads, gold earrings, iron bracelets, bronze and iron knives, bronze arrowheads, and horseshoes and domes.

The hand-crafted pottery found in the Sakarchaga does not differ much from the Kuyisay settlement pottery, and they form technologically common forms of pottery. Another group of pottery was made on a pottery wheel and brought from Margiana and probably from Bactria to the Khorezm oasis. Such vessels belonging to Yoz II period in Margiana were found in Uygarak fortresses and Kuyisay settlement.

L.T. Yablonsky compared the bronze and iron artefacts and horse equipment in the Sakarcha archeological complex with similar finds belonging to the steppe tribes of the Early Iron Age, which spread over a wide area - along the Volga, the Southern Urals, Kazakhstan and Western Siberia and proposed to mark the Sakarchaga cemeteries with the end of the $8^{\text {th }}$ century and the $7^{\text {th }}$ century[24]. However, similar Yoz II period pottery found in the Southern Tagisken and Uygarak fortresses, with some bronze arrowheads and iron blades, is the boundary of the Lower Amu Darya, the Southern Aral Sea region by the first Saks in the $8^{\text {th }}-7^{\text {th }}$ centuries BC. It can be associated with the $7^{\text {th }} 6^{\text {th }}$ centuries.

Archaeologists from Turkmenistan and Karakalpakstan discovered nomads in the deserts between the Aral and Caspian Seas and in the northwestern borders of the Khorezm oasis as a result of excavations and archeological excavations in the Uzbay and Ustyurt basins of the Amu Darya in the Caspian Sea in the 1970s and 1980s. In this regard, the discoveries of D. Durdiev, H. Yusupov and VN Yagodin should be mentioned.

Most of the nomadic burial mounds found in the middle and upper Uzbay ridges date back to the $4^{\text {th }}-2^{\text {nd }}$ centuries, as well as some belong to $6^{\text {th }}-5^{\text {th }}$ centuries[25]. Relevantly B.I. Weinberg writes that in the $6^{\text {th }}$ century BC, the settlements of massagets on the shores of the Uzbay did not yet exist[26]. But the Massagets were tribes that migrated over large areas. In our opinion, their settlements were characterized by short-term spaces belonging to the nomadic way of life. This is evidenced by the results of research in the western and eastern parts of Ustyurt[27].

The first Saks, who migrated from the Lower Syr Darya to the left bank of the Lower Amu Darya, lived in basements and huts in settlements that were not surrounded by defensive walls. On the border of $7^{\text {th }} 6^{\text {th }}$ centuries BC, the fortress of Kozalikir was built around Sarikamish region, in the middle part of Dovdon basin. The use of raw bricks and wattle and daub as building materials, the defense system, the palace and the prayer center, the production of pottery in the pottery wheel, and the separation of the blacksmith profession were identified in Kozalikir in relation to the cattle-breeding settlements of Kanga 2 and Kuyisay 2[28].

These news testify to the radical changes in the cultural and ethnic history of the Khorezm oasis. However, these changes were reflected only in the archeological materials obtained on the lands of the left bank of the Amu Darya, and in the territory of the right bank of the Amu Darya no monument like Kozalikir was found.

At the beginning of the $21^{\text {st }}$ century, new research has emerged on the history of the ancient population of the Khorezm oasis, the Aral Sea. Analyzing the scientific views and conclusions put forward 
in A.A. Askarov and S.P. Tolstov's monographs, it was concluded that "productive pastures in the Khorezm oasis were very favorable for the development of animal husbandry" from the Bronze Age, when irrigated agriculture did not develop rapidly in Khorezm as welle as Kuyisay tribes were local representatives of the oasis[28].

According to Q. Sabirov, in the $7^{\text {th }}$ and $6^{\text {th }}$ centuries BC, groups of people along the Sariqamish Basin of the Amu Darya were engaged in nomadic pastoralism, while the Kuyisays "lived in tents and barns, engaged in spring farming and animal husbandry" [29].

The researcher found that in the $9^{\text {th }} 8^{\text {th }}$ centuries BC, the connection of the right bank with the tribes of the Amirabad culture, which developed in the Akchadarya basin of the Amu Darya, probably came true. Also Q. Sabirov suggested that the "Saks of water" and "Massagets of swamp" mentioned in Strabo's work must have been from Amirabad people.

In our opinion, it is possible that the Kuyisays originated from the Amirabods. However, it is natural that the question arises as to which tribes the population that left material evidence in the tombs of Sakarchaga belonged to. It is clear that the materials obtained in the tombs of Sakarchaga belong to the culture of the first Saks.

Gh. Khodjaniyazov's monograph analyzes the defense system of Chirikrabot and Bobishmulla, the weapons of the Saks, bronze and iron daggers, bows and armor[30].

According to $\mathrm{H}$. Matyakubov, in the $7^{\text {th }}$ century BC, complex ethnic processes took place in the Southern Aral Sea region, and it is not appropriate to interpret the Kuysays as tribes who migrated from the south, because their way of life did not reflect the systemic cultural traditions of the southern regions of Central Asia. "On the contrary, according to the main features, the integral connection of the culture of Kuyisay with the cultures of steppe herders prevails". Thus, the researcher came to the conclusion that the indigenous population of the left bank of the Khorezm oasis, conventionally called "Kuyisays", were the heirs of the tribes that created the culture of Amirabad[31].

In our opinion, it is important to take into account the results of archaeological research in the interpretation of ethnic and cultural processes that developed in the regions of Sarikamish in the $7^{\text {th }}$ century BC. B.I. Weinberg correctly quoted the peculiarity of the Kuyisay culture. The researcher noted that the basis of the economy of the Kuyisays was cattle-breeding, and that this culture generally belonged to the Sak culture. Evaluating this approach, V.M. Masson wrote that the dwellings were typical of the material culture - the sites and hand-made pottery reflect the traditions of Saxon pottery[32].

In fact, there are many similarities in the style of the ribbon found in the excavations to Sakarchaga in the forms of hand-made pottery and in the pottery of Kuyisay. They are also seen on bronze and iron weapons as well as on the tips of bronze bullets. It is not expedient to ignore the emergence of a semisedentary and sedentary livestock lifestyle in the $8^{\text {th }}$ century on the lands of the lower left bank of the Amu Darya. It is probably correct to call the tribes that created this culture as "Khorezmians-Saks" according to the leading cultural symbols.

The Kozalikir culture, which originated in the Early Iron Age on the banks of the Sarikamish River, differed greatly from the culture of the early Saks. O.A. Vishnevskaya and Y.N. Rapoport connects the culture of Kozalikir with the first stage of development of the ancient Khorezmian civilization, and speaks about the introduction of innovations in Khorezm in the field of previously unknown construction and architectural methods, defense system, crafts.

Archaeological excavations and finds in the Southern Aral Sea region have raised the need to periodize the history of the Khorezm oasis of the Early Iron Age. With this in mind, S.B. Bolelov divided the history of the first Iron Age oasis into the following stages: the first stage - the end of the $8^{\text {th }}$ century and the beginning of the $7^{\text {th }}$ century BC, the migration of the first Saks from the Lower Syr Darya to the regions along the Sarikamish, formation of the Kuisay culture; the second stage - the end of the $7^{\text {th }}$ century, the formation of the Kozalikir culture and the emergence of a pottery center in Khumbuztepa (Southern Khorezm) [33].

S.R. Baratov wrote about the inspection of the first Saxon tombs in Southern Khorezm (right bank of the Amu Darya), such as Meshekli and Uchochoq. The researcher noted that the bronze bullet tips and hand-crafted ceramic vessels identified among the burial mounds make it possible to mark those fortresses with the $8^{\text {th }}-6^{\text {th }}$ centuries $\mathrm{BC}$, the obtained materials can serve as a basis for the inclusion of the territory of South Khorezm in the territory of the Kuisay culture, from which local cattle-breeding tribes spread to the Uzbay River and Ustyurt[34].

Researchers who discovered and studied the monuments of the Kuyisay culture (B.I. Weinberg, D. Durdiev) marked these monuments by the $7^{\text {th }}$ century BC. At the same time, However, L.T. Yablonsky and S.R. Bolelovs 'views that the Kuyisay culture emerged as a result of the migration of the first Saks, are true and the Kuysays are interpreted as the heirs of the tribes of the Amirabad culture.

The following conclusions can be drawn from above observed ideas: 
1. In the study of the history and culture of the Saks, the knowledge of ancient Persian writings and Greek historians is important, and they have been considered by researchers of different generations. Written sources have been interpreted more in relation to the domestic and foreign policies of the Persian kings (Cyrus II, Darius I), and since the late $19^{\text {th }}$ century, orientalists have raised issues about the etymology of the Saks, their territorial location, historical geography, and social system.

2. Opinions expressed until the late 1940s should be interpreted as scientific hypotheses. Since Western orientalists were not in Central Asia, they tried to determine the boundaries of the territorial location of the Sak-Massagets and issues of historical ethnography, using the available historicalgeographical information and geographical maps. Although the research done in this area is far from certain historical results in terms of its characteristics, they formed the basis of the scientific direction of source studies, historical geography and ethnic cartography in the study of sak-massagets.

3. This important fact was not overlooked during the beginning of archeological research of the culture of the Aral Sea Saks. At the same time, the research plans of the Khorezm archeological expedition are aimed at studying the history of steppe cattle-breeding tribes.

In the southern part of the Lower Syr Darya delta (Inkardarya tributaries) the first Sak settlements and burial mounds (South Tagisken, Uygarak) were identified. It was found that cattle-breeding tribes had a semi-nomadic lifestyle and lived in settlements not surrounded by defensive walls.

4. In the second period, which began in the $5^{\text {th }} 4^{\text {th }}$ centuries BC (Chirikrabot and Jetiosor culture) in the Lower Syr Darya basin were built large castles and houses, agriculture played an important role in the economic life of the population.

As a result of many years of research of the Khorezm archeological expedition, the defense structures, architectural features, handicrafts and the ancient artificial irrigation system of the Eastern Aral Sea (Lower Syr Darya) Saks of the $5^{\text {th }}-3^{\text {rd }}$ centuries BC were studied.

5. Until the $70 \mathrm{~s}$ of the $20^{\text {th }}$ century, in the scientific literature, Khorezm, like neighboring Sogdiana, Bactria and Margiana, has long been considered as a country with a settled agricultural and cultural form. Therefore, in order to study the culture of the steppe tribes surrounding the Khorezm oasis, the theme "Scythians of the Aral Sea and Khorezm" was put forward.

However, as a result of the discovery of the Kang 2, Kuyisay settlements and Sakarchaga burial mounds, the existing scientific views changed, and along with the concept of "Eastern Aral Sea Saks" the terms "Southern Aral Saks" and "Saks - Khorezmians" appeared. Based on the material evidence obtained, it was found that the socio-economic relations of the early Saks developed based on the traditions of the tribal system.

\section{CONCLUSION}

By the end of the 1990s, scientific views on the ancient history of the Aral Sea population, including opinions about the emergence of slavery in Khorezm in the $8^{\text {th }} 7^{\text {th }}$ centuries changed, and it was necessary to reconsider the unproven conclusions on the basis of new data, because the views of the Khorezm expedition on the history of Khorezm and the Aral Sea Saks were accepted in Central Asian history for many years, recognized in ancient historiography. In this regard, it should be noted that the new views and approaches were first of all reflected in the works of researchers of the Khorezm expedition. There was a definite systematic scientific view of the Sak culture, but they were in many respects the contents of archeological problems, and the history of the first Sak tribes of the Aral Sea was not considered as a separate generalized special subject.

Thus, in the study of the history of the first Saks of the Aral Sea, written and material sources are distinguished by their relevance. The history of the Aral Sea cattle-breeding tribes is limited to written sources. But perceptions of the early Saks were primarily based on the same sources, which made it possible to determine the sequence and dates of some of the events that took place through them. Inscriptions from the past and the works of ancient authors can also serve as a basis for discussing the ethnicity of different groups of breeders. In the absence of material sources in this regard, written data, by their importance, form the basic sources in the process of reconstructing historical events.

The role of expanding archeological materials in advancing scientific issues and developing new topics on the history of the Aral Sea Saks is enormous. They are a determining factor in the dynamics of the development of knowledge about the historical past. It is especially important to compare the results of written sources and archeological research in the process of historical reconstruction.

\section{References}

1. Tolstov S.P. On the footsteps of Khorezm civilization. - M., - L: 1948. - P. 133-134.

2. Levina L.M. On the history of research of the Khorezm archaeological and ethnographic expedition in the Eastern Aral Sea region // Aral Sea region in antiquity and the Middle Ages. - M.: 1998. - P. 42. 
3. Bartold V.V. Report on a trip to Central Asia with a scientific purpose. 1893-1894. 22. // Essays. - M.: Наука, 1966. V. IV. - P. 26-29;

4. Tolstov S.P. Khorezm archaeological and ethnographic expedition of the Academy of Sciences of the USSR in 1946 // Bulletin of the Academy of Sciences. - M., 1947. V. 4. №2. - P. 177-182.

5. Weinberg B.I., Levina L.M. Chirikrabot culture // Lower reaches of the Syr Darya in antiquity. - M., 1993. $1^{\text {st }}$ edition. - P. 37-56.

6. Tolstov S.P. Along the ancient deltas of the Oxus and Jaxart. - M.: 1962. - P. 155. Picture map 85.

7. Tolstov S.P., Itina M.A. Saks of the lower reaches of the Syrdarya (based on materials from Tagisken) // CA. - M., 1966. №2. - P. 151-175

8. Tolstov S.P., Zhdanko T.A., Itina M.A. Works of the Khorezm archaeological and ethnographic expedition in 1958-1961. - M., 1963. $6^{\text {th }}$ edition. Part 1. - P. 34.

9. Vishnevskaya O.A. The culture of the Saks tribes of the lower reaches of the Syr Darya in the $7^{\text {th }}-5^{\text {th }}$ centuries. BC // - M., 1973. V. VIII. - P. 160.

10. Vishnevskaya O.A., Itina M.A. Early Saks of the Aral Sea region. Problems of Scythian archeology // №177. - M., 1971. - P. 201-207.

11. Levina L.M. New research of the monuments of the Jetiasar culture in the Eastern Aral Sea region // Early nomads of Central Asia and Kazakhstan. - L.: Наука, 1975. - Р. 42-46.

12. Itina M.A. Khorezm Expedition - Main Results and Research Prospects // Culture and art of ancient Khorezm. - M.: Наука, 1981. - P. 10.

13. Tolstov S.P. Aral Sea Region Scythians and Khorezm // CЭ. - M., 1961. №4. - P. 114-146; The same author. Central Asian Scythians in the light of the latest archaeological discoveries //- M., 1963. №2. - P. 23-45.

14. Weinberg B.I., Durdiev D., Yusupov Kh. Exploration work in Northern Turkmenistan // AO 1970. - M.: 1971. - P. 434-436.

15. Durdiev D. Archaeological research in the Tashauz region // Karakum antiquities. - Ashgabat, 1977. $5^{\text {th }}$ edition. - P. 137-139.

16. Weinberg B.I. New culture of the early Iron Age in the left-bank Khorezm // AO 1971. - M.: 1972. - P. 530-531;

17. Weinberg B.I. Cattle-breeding tribes in ancient Khorezm // Culture and art of ancient Khorezm. - M.: 1981. - P. 128.

18. Itina M.A. From the editor // Nomads on the borders of Khorezm. Tp. ХАЭЭ. Volume XI. - M., 1979. P. 5-6.

19. Trofomova T.A. Skulls from the burials of the Kuyisay culture in the burial grounds of TumekKichidzhik-i Tarym-kaya // Nomads on the borders of Khorezm. Tp. ХАЭЭ. Volume XI. - M., 1979. - P. 79.

20. Weinberg B.I. Monuments of the Kuyisay culture // Nomads on the borders of Khorezm. Tp. ХАЭЭ. Volume XI. - M., 1979. - P. 48.

21. Itina M.A. Security archaeological work in Khorezm: results and prospects // CЭ. - M., 1984. №1. - P. 53.

22. Yablonsky L.T. Exploration of the Sakarchaga burial ground // AO 1981. - M.: 1983. - P. 482-483;

23. Yablonsky L.T. Saks of the Southern Aral Sea region (archeology and anthropology of burial grounds. - M.: Institute of Archeology RAS, 1996. - P. 18-21.

24. The above shown work. - P. 50-52. Also see: Itina M.A., Yablonsky L.T. Saks of the Lower Syr Darya. M., 1997. - P. 93-107; Yablonsky L.T. Saks of Oks delta. Theory and practice of ethnogenetic research. - M., 2015.

25. Yusupov Kh.Y. Exploration of burial sites along the upper Uzbay in the spring of 1973 // Successes of Central Asian archeology. - L.: 1975. 3 ${ }^{\text {rd }}$ edition. - P. 48-51;

26. Weinberg B.I. The ancient history of the watering of the Sarikamish delta of the Amu Darya in the light of archaeological work of the last decades // Aral crisis. - M., 1991. - P. 130.

27. Yagodin V.N. Nomads on the northwestern borders of Khorezm // Loan action of nomadic cultures and ancient civilizations. - Alma-Ata, 1987. - P. 133-135;

28. Vishnevskaya O.A. Excavations at the settlement of Kozelikir // A0 1971. - М.: Наука, 1972. - P. 532533 ;

29. Askarov A. Some issues on the history of ancient Khorezm // Ethnology of Uzbekistan: new views and approaches. - Tashkent, 2004. - P. 76-84;

30. Sobirov Q. Defense structures of villages and cities in Khorezm. - Tashkent: Fan, 2009. - P. 135.

31. Khodjaniyazov Gh. Ancient Khorezm defense structures. - Tashkent: O'zbekiston, 2007. - 216 p.

32. Matyakubov H. History of the Bronze Age and the Early Iron Age of Khorezm oasis. - Tashkent, 2017. - P. 36-37. 
33. Masson V.M. Civilization of ancient Khorezm (stages and ways of self-identification) // - Samarkand, 1999. $30^{\text {th }}$ edition. - P. 88-89.

34. Bolelov S. The early period of the history of ancient Khorezm according to archaeological data // Archeology, history and culture of Central Asia. - Tashkent, 2002. - P. 44-45; 